\title{
Social movements in Cambodia: why they succeed or fail
}

\section{Sokphea Young}

Email: sokphea.young@ucl.ac.uk

\begin{abstract}
In social movements and contentious politics, the factors determining success or failure of a movement remain contested since different scholars tend to argue differently. As a contribution to this debate, this paper draws on two cases representing the relative success and failure of movements targeting the government of Cambodia and foreign joint venture investments to address the communities' grievances. The paper reveals that, while other factors such as strategies, resource mobilisation, networks and corporate behaviour remain necessary to the debate, the variation in outcome is essentially determined by the patron-client network, a political dynamic employed by the neo-patrimonial rulers to cling onto power.
\end{abstract}

Keywords: neo-patrimonialism; patron-client network; political opportunity structures; social movement outcomes; success or failure. 


\section{Introduction}

In the context of social movements and contentious politics, groups of disgruntled people or organisations tend to make claims over one another in pursuing their respective interests. Scholars investigating this field tend to focus on the dynamics, patterns, structures and emergence of the interactions between these groups, rather than on their outcomes (McAdam et al. 2001; Olzak and Soule 2009; Soule 2009; Tarrow 2012; Van Dyke et al. 2005). Although outcomes of movements have recently received attention, few attempts have been made to theorise their success or failure. A number of scholars have endeavoured to define the factors determining success or failure (Bosi et al. 2016) - known as the extent to which movements respectively achieve or fail to achieve their demands - but their propositions remain inconclusive. As a contribution to resolving this puzzle, this study explores why some social movements fail while others succeed within a neo-patrimonial regime. The regime that is defined as 'a form of organisation in which relationships of a broadly patrimonial type pervade a political and administrative system which is formally constructed on rational-legal lines' according to Clapham (1985: 48).

The paper draws on two cases of community movements, one relatively successful and the other a relative failure. ${ }^{1}$ These two cases are purposely selected in order to theorise the decisive factors explaining the variation in outcomes of social movements in land and extractive industries. This paper argues that, in one case, the movement relatively failed because their actions threaten companies that have strong political ties, manifested by patron-client networks, with the neopatrimonial government of Cambodia. Conversely, other movements relatively succeed because their actions target companies with weak political ties to the government. Thus, while other factors, such as the movements' strategies, aligning with political elites, networks and resource mobilisation, also contribute to the variation in outcomes of social movements, the patron-client networks of neo-patrimonial politics is rather the decisive one.

To unpack this argument, the remainder of the paper is organised into three sections. The first section reviews and then develops theoretical propositions that underpin success or failure of social 
movements by drawing from the literature of neo-patrimonial politics. The second section discusses the empirical findings of two case studies of relative success or failure. Finally, the paper links these issues together and concludes by arguing that the interlocking patron-client networks of neopatrimonial politics primarily determine the relative success or failure of disgruntled communities.

\section{Factors underpinning consequences of social movements: success or failure}

While social movements have been acknowledged as contributing to political, social, cultural, policy and institutional changes as their outcomes (Cai 2010; Soule 2009), these outcomes are rather broad and difficult to measure. To avoid this, other scholars posit two important types of outcomes: direct and indirect. Direct outcomes include the benefits and achievements gained from their targets (government/state or companies) by disgruntled groups (Gamson 1990), whereas indirect outcomes consist of changes in public perception and biographical changes and/or cultural changes and institutional effects (Giugni 1998). To synthesise, this study argues that direct outcomes can be defined simply as the goals, claims and demands of a movement or known as intended consequences; indirect outcomes, known as unintended impacts, of social movements, consist of changes in the behaviour and knowledge of participants, capacity of the participants, raising public awareness about the issues, and even the environment. While the paper acknowledges that these unintended consequences are important to some scholars and activists, measuring the degrees of success or failure of a movement has to do with direct outcomes. Gamson (1990) defines successful outcomes of movements as the acceptance of a challenger group by its antagonist as a valid speaker for a legitimate set of interests and the gaining of new advantages by the group's beneficiaries during the challenge and its aftermath. To measure the degrees of success or failure, this paper, instead, compares the expected outcomes, including claims, demands, and stated objectives, against the actual achievements or responses (what Gamson calls the 'full response') of the targets including states, governments, corporations or international organisations. If the targets respond positively, a movement, to a certain degree, succeeds in achieving their demands; the 
movement otherwise fails. To understand under what conditions the movements succeed or fail, it has to understand the causal factors leading to either success or failure of the movements. The factors suggested by social movement scholars below are considered as independent explanatory variables, while the outcomes of movements are the dependent ones. However, the decisive independent factors which explain the outcomes remain contested among the scholars.

The first one is the use of tactics, comprising of non-violent and violent tactics; and structural organisations, such as formal and informal arrangement. These have shaped the success or failure of aggrieved groups (Stephan and Chenoweth 2008; Gamson 1990; Cress and Snow 2000). Nonviolent tactics, such as peaceful protests and petitions or those activities that are not harmful or unlawful, tend to be more effective than violent tactics, such as violent protests, sit-ins, road blockages and vandalism, which tend to face severe repression (Stephan and Chenoweth 2008). However, the debate between non-violent and violent tactics remains in the existing social movement literature. Drawing on resource mobilisation theories, another group of scholars (Edwards and McCarthy 2004) affirms that resources - including, but not limited to financial support, participation of members, knowledge and capability - are crucial factors determining the outcomes of movements in general, and success or failure of movements in particular. They hypothesise that, if a movement has enough resources, it tends to succeed; otherwise it fails. Influenced by resource mobilisation theories and new social movement concepts, Keck and Sikkink (1998) argue in their work on transnational advocacy networks that dense networks of movements and civil society organisations leverage influence on the targeted institutions. These networks empower domestic movements to resist repression by the domestic government, and mobilise international community pressure on the latter. This boomerang approach thus, it is argued, increases the chances of success.

The second factor is political opportunity structures, formal or informal opportunities that encourage (open to) movements. While the concept is still debatable, scholars in the field argue that if movements align themselves with the political elites within a conducive political system, they 
tend to leverage influence to attain their expected outcomes that are more successful (Sikkink 2005). They fail to achieve their expected outcomes if the political system does not open to their demands, thereby discouraging movements (Amenta et al. 1999; Amenta et al. 2002; Fox and Cloward 1993; Gamson 1990; Sikkink 2005). Although this notion is widely believed to have significant effects in social movements, Gamson and Meyer (1996) contend that political opportunity structures are too broad to explain every social movement, and thus there is disagreement among scholars and pundits with respect to the effect of political opportunity structures on social movement outcomes. The notion of political opportunity structures does not explain every outcome of movements in different political contexts (Meyer and Minkoff 2004).

The third and last factor to discuss in this study is concerned with the overall political environmental context. Influenced by revolution and regime change, it is claimed that the degree of success or failure has to do with political contexts. These scholars, such as Amenta et al. (2010), Cress and Snow (2000) and Chenoweth and Stephan (2011), assert broadly that political contexts are vital causal drivers that underlie whether a movement succeeds or fails. They argue that movements in democratic countries tend to face more concessive than repressive measures, so they achieve more successful outcomes than do movements in authoritarian countries. They furthermore contend that movements fail because they tend to threaten or overthrow the regime (Cai 2010). This remains inconclusive, as political contexts vary considerably and movements do not always succeed in democratic regimes. Some scholars argue that the rightful movements of aggrieved groups in authoritarian regimes succeed because these regimes tend to placate the citizens in order to avoid social unrest or political chaos (Cai 2010). Thus, the aforementioned conceptions fail to explain inclusively the dynamics and conditions of how movements fail or succeed.

This paper contends that, although the foregoing independent factors are necessary for explaining the degrees of success or failure of movements, they are competing and so inconclusive. They are mostly drawn from movement cases in Western countries, where the target is solely a government or state in a pure political system, either a democratic or authoritarian country, but not 
in a hybrid political system, like the ones this study addresses. Furthermore, none of the studies have considered how the theoretical concepts of neo-patrimonial politics determine the success or failure of a movement. Although the link between the neo-patrimonialism and social movements is partially explained in the concepts of political context and political opportunity structures, these have not been explicitly explored in the developing and non-fully democratic countries.

\section{Neo-patrimonialism and its patronage and clientelism}

The term 'neo-patrimonialism' is derived from 'patrimonialism', which is known as the right to rule being ascribed to a person rather than an office (Weber 1978); it re-emerged in the mid-1980s. Clapham (1985) asserts that, in neo-patrimonialism, officials hold a formally defined position in administrative organisations but they exercise powers as a form of private property.

Clapham, however, fails to explain the operationalised concept of neo-patrimonialism, although he identifies corruption and the patron-client relationship as the measurable indicators (Clapham 1985). Bratton and Van de Walle (1997) point out two important aspects of neopatrimonialism: hybrid political systems whose customs and patterns of patrimonialism exist alongside each other; and rational-legal institutions. However, Erdmann and Engel (2007) criticise the above definitions as ambiguous because they fail to provide operationalised, measurable indicators. They emphasise that the definition of Bratton and Van De Walle $(1994,1997)$ is more applicable in African regimes and is dominated by the concept of presidentialism. Influenced by Scott (1972), Erdmann and Engel (2007) propose clientelism and patronage as crucial operationalised indicators of neo-patrimonialism. Both clientelism and patronage imply the politically motivated distribution of favours that aims to promote personal political interests which benefit the neo-patrimonial regime. Clientelism implies a dyadic and asymmetrical nexus between patron and client, while patronage is understood as the relationship between an individual person and a bigger group. The difference between clientelism and patronage is essentially a distinction between the recipients - between individual ownership (land, office, services) and public or 
collective benefits, such as roads, schools, etc. (Erdmann and Engel 2007). These imply that patron and client networks are embedded within neo-patrimonialism.

According to Scott (1972), the patron-client relationship (an exchange relationship between roles) is a dyadic tie involving a largely instrumental friendship in which an individual of higher socio-economic status (the patron) uses their own influence and resources to provide protection or benefits, or both, for a person of lower status (the client); the latter, for their part, reciprocates by offering general support and assistance, including personal services, to the patron. From a rural and agrarian perspective in Southeast Asia (Thailand, Malaysia, Myanmar etc.), Scott (1972) introduces several mechanisms of relationship flows between patron and client - protection, brokerage and influence, and collective patron services. Protection shields clients from either private (banditry, personal enemies) or public dangers (military, external officials, courts and taxes), and is perhaps carried out by armed forces or by pledging revenge on behalf of the client. Brokerage and influence can be leveraged through protecting the client from outside intruders by using the patron's power to influence those others, as well as extracting rewards from the outsiders for the client. Collective patron services, which should be a benefit for the client, are public economic performances of the patron through donating and supporting public facilities for communities. As explained above, the flow from client to patron shares the benefit that the client earns from the patron's protection. These theoretical concepts suggest that any movements that tend to alter the economic activities of the client or the reciprocal benefits of the patron-client network tend to fail to achieve their demands, at least in part, because the client is protected by the central patron; the movement otherwise succeeds.

\section{Cambodia as a neo-patrimonial regime}

After the collapse, in 1979, of the genocidal regime in which approximately 1.5 million Cambodians died due to starvation, forced labour and disease, the country has transformed its politics and economy. As space is limited, merely a glimpse of the transformation is provided here. Economically, Cambodia has transformed itself from a centrally planned economy to a free market 
economy and has striven to integrate itself into regional and international communities. Politically, Cambodia has transitioned from communism to a superficial form of democracy. After the Paris Peace Agreement in 1991, the UN was authorised to ensure peace reconciliation and this led to their organising elections in 1993. Since then, Cambodia has begun to move from an authoritarian to a democratic regime. However, although the country has gone through five consecutive rounds of national elections, democratisation is still incomplete. Apart from the current structure being known, variously, as 'electoral authoritarianism', 'neo-authoritarianism', and 'hybrid or new democracy' (Un 2005), Cambodia's form of government is generally known as a neo-patrimonial regime (Hughes 2003; Un 2005; Un and So 2011) because of, but not limited to, the following characteristics.

Prime Minister (PM) Hun Sen and his colleagues have controlled the government since the 1997 coup d'état. Hun Sen has, in fact, served as Minister and PM since 1984 (Hughes 2003). Although the unprecedented and unanticipated 2013 election results - in which Sen's Cambodian People's Party (CCP) lost popularity and suffered a decrease from 90 per cent to about 60 per cent of the national assembly seats - have given a wakeup call to the regime, the CCP has managed to remain dominant. This regime, in which patron-client networks are firmly entrenched, survives because of patronage and clientelism (Hughes 2003; Peou 2001). Through these networks, Sen has deliberately maintained what this study calls 'partial political legitimacy'. Peou (2001) argues that Sen's political administration survives because of the goodwill of his coalitions, who reap the benefits of the CPP's power and support of Sen to remain in power. In such a network, one can be either a client of the top or central patron, or the (middle) patron of a client at the lower level. If assistance is needed, the client at the lower level seeks help and intervention from the middle patron, and the middle patron continuously seeks intervention and help from the central patron (Hughes 2003). This is an interlocking network, like a boomerang from the central to the local level, the practical effects of which can be seen in several aspects, such as appointment to lucrative positions and rent-seeking. 
In the current era of economic liberalisation, Cambodia has, since the early 1990s, strategically exploited natural resources, and this has benefited the regime's legitimacy. ${ }^{2}$ This is affected not only by awarding lucrative positions in the government administration, but also by allocating natural resources (Hughes 2003). In particular, licences for extraction of resources (mining, oil, agricultural land, logging and energy) and privatisation of state properties are awarded to individuals who are loyal to the ruling party. Benefits/rents extracted from such lucrative investments have to be shared with the patron and/or financially contributed to the ruling party to influence election outcomes. Close to election periods, such benefits are used as gifts or donations in terms of material gifts (clothes, food, rice, fertiliser, etc.) and the construction of physical infrastructure (schools, roads, pagodas, irrigation systems, etc.) in return for votes (Un 2005). Given the roles of business in this regime, the dividing line between private and public sectors is blurred. The patrons strive to become involved in business activities so as to grab the state's resources or benefit from other kinds of privatisation. Wealthy businesspeople connect with powerful government officials by making financial contributions to the CPP and the government in return for business deals in lucrative sectors (Hughes 2003; Un 2005). Coupled with lax and uncertain regulatory enforcement (Young 2016a), natural resource extraction, especially from land resources, has caused adverse accumulated impacts on more than half a million people (ADHOC 2014). These impacts have provoked the affected communities to mobilise simultaneously against the government and its affiliated joint-venture companies (Young 2016b).

Some communities are reported to have succeeded in achieving most of their demands, while other communities have not. So far, none of the scholarly work has documented why and how some of these movements have succeeded while others have failed in this neo-patrimonial regime. A study of small-scale land disputes suggests that political mobilisation is a necessary precursor to the success of these collective groups, which have to be very well organised and able to persuade highlevel decision-makers (Adler et al. 2006). Apart from its limited theoretical development, the latter study suggests that use of tactics, such as seeking support from high-ranking officials within the 
government administration, is important to ensure success. However, the study fails to suggest decisive political factors associated with the responses of the powerful persons, company officials and governments involved in those land disputes. Parnell (2015) studied the protests of environmental groups in Prey Lang in Cambodia and places the dynamics of these movements within social change, rather than explaining the factors contributing to the protests' ultimate objectives - that is, influencing the government to maintain the forest. Marston and Hoeur (2015) investigate grassroots mobilisations pertaining to a reservoir in the floodplain of Cambodia; they suggest that the aggrieved villagers/protesters take their grievances to the polls, voting for either the opposition or ruling parties, in order to protect their common interests. This illustrates how protests can affect the patron-client relations of the political parties in disputed areas.

Milne (2015) looks at the dynamic nature of neo-patrimonialism in Cambodia, highlighting how patronage has formed like a pyramid around one central power to extract rent from logging and other natural resources such as land. The rent is shared among the political elites and the top patron of the neo-patrimonial regime (Hun Sen). Milne et al. (2015) have clearly demonstrated how patronage networks are constructed in order to extract rent from land and natural resources, and are used to influence election results and even to maintain power and party dominance (Pak 2011). Similarly, Un and So (2011) suggest that neo-patrimonial networks undermine land reform in Cambodia, because land and natural resources are seen as sources of rent to be extracted by the regime's rulers. While Un and So (2011) and Milne (2015) do not explore thoroughly how natural resource-dependent communities react to rent extraction and the outcomes, these studies not only offer substantial evidence of how neo-patrimonial rules and their networks operate in Cambodia, but also suggest a framework for the analysis of how these networks undermine the resistance of the communities and contribute to their success or failure. Hence, it is imperative to place the variation in outcomes of community movements within the context of the neo-patrimonial ruling structure.

To fill this empirical gap, two cases of social movements, one relatively successful and the other a relative failure, are drawn upon for in-depth observation. The two cases have been selected 
for two reasons. One case (the sugarcane case) is concerned with the lingering resistance of the local communities, which targeted an entrenched patron-client network. Sustained and assisted by NGOs, this case has been struggling to influence the government and the companies involved for more than a decade. Although it has become a model for other cases in the country, it has failed to achieve most of the demands. The other, relatively successful case (the rubber case) involved less support from NGOs and lasted for a shorter period, but achieved most of the demands. Within the neo-patrimonial context, the variation in outcomes of these two cases raises both theoretical and empirical questions. Hence, the two cases relate to both theoretical and empirical literature pertaining to social movements in this political context. In the sections that follow, the paper explains the dynamics and outcomes of contention among the communities, the government and two agro-industrial companies.

\section{A successful case: rubber agro-industry}

In early 2007, two foreign (Western) companies were granted economic land concessions (ELCs). Rubber Big and Rubber Small ${ }^{3}$ were awarded ELCs of about, respectively, 4500 hectares and 3000 hectares, each for 70 years. A Cambodian oknya (wealthy person or tycoon), who was the owner of the company Kam, owned both Rubber Big and Rubber Small. After almost a year of land preparation, the company Kabe took over the management and operation of the two ELCs as a joint venture with Kam, and it became known as the rubber company Kabe-Kam; Kabe held 70 per cent and Kam owned 30 per cent of the total shares. In early 2008, the indigenous communities in the Bousra commune were surprised when the rubber company cleared not only their forestland, but also other properties, such as farmlands, cottages and crop plantations. Tension between the rubber company and the indigenous communities erupted. According to the International Federation for Human Rights (2011), about 850 families were affected by the rubber company's operations. The indigenous communities then launched movements to influence the government and the rubber company simultaneously to address the following demands: ${ }^{4}$ 
- returning about 1500 hectares of farmland or offering fair cash compensation,

- respecting the rights of indigenous communities,

- mitigating cultural issues: the sacred forest and cemeteries,

- conserving the forest for non-timber forest products (NTFPs) and

- mitigating soil erosion.

To achieve these demands, the indigenous communities staged a two-phase movement. The indigenous communities at first believed that they would succeed if they could leverage pressure on the government to regulate the rubber company; otherwise, they believed they would fail. The communities initially organised petitions and peaceful protests, and later filed complaints with the commune, district, provincial office, and provincial departments of the land and agriculture and related ministries. In April 2008, as the rubber company started to raze the indigenous people's plantations and worship sites, the communities consulted with village heads and then petitioned the commune and district offices. However, a representative claimed that the local government and rubber company offered no significant responses. ${ }^{5}$ In May 2008, about a hundred representatives of the indigenous communities gathered and protested at the provincial office in Mondulkiri. Even though the National Authorities for the Resolution of Land Disputes intervened, community representatives claimed that they only made empty promises. In October 2008, the representatives of the indigenous communities filed complaints regarding the adverse impacts of the rubber company's activities to the Councils of Ministers, the Ministry of the Interior and the Ministry of Land Management, Urban Planning and Construction in Phnom Penh. However, the representatives argued that there was no immediate positive response or intervention undertaken by these institutions (FIDH 2011).

Given the lack of acceptable results from the initial movement, the communities subsequently launched violent protests to leverage pressure directly on the rubber company and indirectly on the government. The representatives described that, on 20 December, 2008, about five hundred affected indigenous people marched with sticks, axes, bottles of gasoline, lighters, knives and other tools 
from the commune office towards the concession areas. ${ }^{6}$ The protesters then incinerated three bulldozers and vandalised a fourth. ${ }^{7}$ With little support from NGOs, a representative said that the communities perceived that the rubber company would not address their demands without significant, violent pressure. ${ }^{8}$

Although police and armed forces that were hired to protect the company observed the violent protest, they took no action to disperse the protesters. A representative claimed that those police instead begged the protesters not to destroy the rubber company's property. ${ }^{9}$ One possible reason that the police and commune did not crack down on the outraged protests was their perception that repressing the protests might provoke an even stronger reaction from the protesters. A representative furthermore claimed that the rubber company had encroached on and destroyed their properties without prior consent or consultation. The communities were thus the victims, not the rubber company. ${ }^{10}$ The commune chief claimed that he was on the communities' side, although he did not endorse the violent protest; he asked the provincial office to solve the problem, but there were continual delays.

However, following a complaint by the rubber company, the police and provincial court of Mondulkiri, on 12 January, 2009, detained six representatives of the indigenous communities. A representative revealed that some of them were charged with robbery, arson and destruction of the rubber company's property; however, the provincial court released them on bail due to the persistent protests of the communities outside the court. A representative said the bail was set on the condition that, if the six representatives spoke to journalists or human rights groups (NGOs) or organised further violent protests, they would be arrested and imprisoned. But the provincial governor refuted this and argued that the representatives had only been summoned for interrogation, and that if the government had actually arrested them, they would have been charged with vandalising the property of the rubber company. ${ }^{11}$ It appears that the provincial governor was trying to protect his image. 
After the violent protests and the release of the community representatives, a representative claimed that they continued to petition the provincial office in Mondulkiri to address their demands. The provincial governor once acknowledged that their protests and petitions were right in informing the government about their concerns. ${ }^{12}$ As a result, a tripartite committee was established, with representatives of the communities, the rubber company and the provincial office and sectoral departments (land, environment and agriculture) to negotiate solutions. After a period of negotiation, the tripartite committee (especially the provincial office representative) decided to reregulate the rubber company, given its limited information about the impacts of the investment. The aims of regulatory enforcement were not only to fulfil regulatory requirements (full social and environment impact assessments), but also to address the demands of the communities. Following a government decision, the rubber company halted its operations for about three months. Meanwhile, the company conducted social and environmental impact assessments, and developed mitigation plans. To meet the demands of the communities, the rubber company: (i) contributed to the conservation of the sacred sites in the forest and the cemeteries by sacrificing buffaloes, offering alcohol to the indigenous people and performing traditional dance; (ii) conserved the forest along the riverbank to avoid soil erosion; and (iii) mitigated surface water contamination by conserving the forest on the riverbank. ${ }^{13}$

In addition to these solutions, the tripartite committee came up with three options to compensate the communities and develop their livelihoods. The rubber company agreed with the government to compensate the communities with cash of 200-250 US\$ per hectare. To compensate for lost fruit trees such as cashew, mango and jackfruit, the rubber company paid 2.50 US\$ per tree, but only if it had borne fruit at the time of the land clearing. Approximately 350 households opted for the cash compensation. Due to different expectations, some of the community members complained that the cash compensation was too low and not enough to acquire another plot of land, yet the rubber company affirmed that it was based on market price. ${ }^{14}$ Another option was a land swap; the rubber company reserved land in another location to exchange with indigenous families 
who had lost land to the concession. However, none of the affected families opted for this option, as the reserved land was located far away from the villages and also full of rocks. ${ }^{15}$ Another option was joint rubber plantation and development; the rubber company allocated plots of land (about 300 hectares) to the affected families for them to plant and grow rubber. In addition to free technical assistance, the rubber company offered fertilisers and replacement rubber saplings as loans. The families who chose this option were obligated to repay the loan after tapping latex from the $9^{\text {th }}$ to the $20^{\text {th }}$ year in 60 -year agreements with the rubber company.

In May 2012, the government issued a moratorium on ELCs and ordered all concessionaires who had caused adverse impacts on local communities to reallocate land to those communities. This moratorium signifies a concessive policy made by the government to reinforce the ELC sub-decree to re-regulate involved companies to address the demands of affected communities. To comply with this, the government and rubber company ceded about 300 hectares from the concession area to each indigenous family, although the general manager claimed that this was unfair to the rubber company because the villagers always wanted land everywhere in the concession areas. ${ }^{16}$ To ensure long-term and sustainable investment, the general manager stated that the company had developed a code of conduct that addressed issues of corruption, working conditions (child labour), relationships with indigenous communities, health of workers and accommodation, among others. To improve its relationship with indigenous communities, the general manager argued that the company had implemented corporate social responsibility practices, including building and maintaining schools, supporting teachers and public health facilities, improving roads and other educational activities. ${ }^{17}$ This was also orchestrated to maintain the company's international reputation in the global rubber market as argued by the general manager.

With the above solutions and mitigation measures, the demands of the indigenous communities, as group discussions suggested, were addressed to a moderate level of satisfaction. ${ }^{18}$ In addition to improved capacity building and advocacy knowledge, and their unity, their grassroots movement achieved a relative success in gaining most of their demands. As noted above, they are 
considered to have achieved success because the government appears to have opted for more concessive than repressive measures in response to their movement. This response shaped the responses of the rubber company and ultimately the achievement of the indigenous communities. Although the influencing strategies of the communities, such as non-violent and violent tactics, seemed to leverage significant pressure on the rubber company and the government, these strategies do not decisively explain why the government opted for more concessive than repressive measures. In particular, after the violent protest the government did not concede but repressed the communities. Thus, it can be argued that the strategic escalation from non-violence to violence cannot decisively explain why the indigenous communities succeeded in attaining most of their demands.

Empirical evidence suggests that a relationship between the client and the patron in this rubber plantation investment does exist but is relatively weak, for two reasons. In order to invest in Cambodia, a foreign investor needs to network with a local broker or develop a joint venture with a local partner, known as an oknya, to access agricultural land. However, as a recent list of the central committee of the CPP suggests, the rubber company's Cambodian partner, although he holds the title of oknya, does not hold a dual position in the party or a government office. The provincial governor claimed that it is not true to claim that the oknya has influenced the government and provincial office. He said 'as you can see, his foreign partner plays significant roles in all decisions, operations and management of the rubber plantation'. ${ }^{19}$ Although the local partner holds an oknya position, he has no strong political ties with the central patron (the PM), according to the central committee list released recently. ${ }^{20}$ So his relation with the top level of government and the ruling party is rather weak, but the relationship has at least facilitated long-term investment. As noted, to access land for a rubber plantation, the rubber company had to seek a joint venture with a Cambodian local partner which had been granted an ELC. As Cock (2011) suggests, no foreign investment in Cambodia can be secured without a joint venture with a local partner. In late 2008, the foreign company joined with the local company (the local partner owned 30 per cent, while the 
foreign investor owned 70 per cent of the total shares). This is the process of securing long-term business in Cambodia, regardless of the requirements of the investment law. The general manager said:

They [local partner] are looking at the opportunities that exist and they direct us in a good way [...]. So it is good to have a local partner that can help you [the foreign company] for all the necessary connections and relations. Who knows how this country is working $?^{21}$

As the interaction suggests, it appears that the communities' relative success in achieving their demands was not due, even in part, to use of tactics - that is, holding peaceful and then disruptive protests; rather, it was mediated by the weak patron-client network between the government and the rubber company. The weak patron-client network is argued to be the main reason because the provincial governor claimed that the adverse impacts were due not only to the malpractice of the company, but also to technical officials from the departments of agriculture, land and environment. In particular, the provincial governor supported the protests of the communities, instead of protecting the company. Although he did not support the violent protest, he said 'All in all, the protest of the villagers to the company is correct [...], the protests inform the malpractice of the companies as well as the government. ${ }^{22}$

This type of statement is rare in a country where most officials tend to support companies. However, due to this company's weak connection, the officials blamed the company for its failure to conduct full impact assessments and mitigate the adverse impacts prior to the land clearance. ${ }^{23}$ Other evidence which supports the interpretation of the weak patron-client network within the neopatrimonial regime is shown by the company being unable to influence officials to order police and guards to disperse the violent protest. In essence, the weak patron-client relation established by the rubber company availed the indigenous communities of leveraging their bargaining power to obtain their claims. 


\section{A case of failure: sugar agro-industry}

Located in south-west Cambodia, four communities have been mobilising against the government and a large-scale sugarcane plantation and sugar-processing investment. This investment was endorsed in 2006 and acquired about 20,000 hectares for a period of 90 years. This concession has been operating in the form of a joint venture between a Cambodian senator and Taiwanese and Thai investors (the sugar company). The senator, who is a CPP politician, owns about 20 per cent of the shares, while 50 per cent belong to the Thai investor and the rest to the Taiwanese investor. In May 2006, operations of this investment caused severe socio-economic impacts on the Chikor Leu commune, ${ }^{24}$ which is home to about 750 households with 3673 people. The affected communities, with the assistance of local NGOs, mobilised promptly against the government and the sugar company to demand:

- return of about 5000 hectares of farmland/paddy fields or offer of fair cash compensation,

- remedy of abuse of human rights (economic rights and land rights),

- resolution of social issues caused by the investment (child labour and student dropouts),

- mitigation of cultural issues (sacred forest and cultural sites),

- conservation of forest for villagers to collect non-timber forest products,

- cessation of kidnapping and shooting of cattle from the communities,

- mitigation of water contamination and

- mitigation of soil erosion.

In order to influence the government and the sugar company to address their demands, the affected communities have, since 2006, employed several tactics, such as peaceful protest, petition, filing complaints to the provincial court and networking with NGOs. In May 2006, the communities petitioned the offices of the Chikor Leu commune, Sre Ambel district and Koh Kong province. The representatives said that, in September 2006, their protests were confronted with severe repression by armed security guards who were military personnel and police, which resulted in shooting, the 
injuring of a woman and the assaulting of four other villagers. ${ }^{25}$ After another confrontation in late 2006, 48 families were successfully persuaded by the government to accept cheap cash compensation; each household received 50-150 US\$. However, this amount was below the land market value. According to group discussions, these families accepted the cash because they were told that either they accepted the cash or the sugar company and the government would confiscate the land, as it was state-owned public land. ${ }^{26}$

In 2007, the remaining members of the communities submitted petitions to the National Senate and the National Assembly of Cambodia, the Ministry of Justice, the Ministry of the Interior (MoI), the Council of Ministers and the Cabinet of the PM, but these institutions took no action to address the communities' demands. A representative said, in March 2008, that the government, led by the Secretary of State from the MoI, intervened in the dispute but later withdrew from the mediation process. Local NGOs claimed that the Secretary of State withdrew due to the influence of the senator, who was a close friend and advisor to the PM. ${ }^{27}$ The group discussions suggested that, to satisfy the rest of the households, the government increased the cash compensation per household to 200 US\$ in 2007, 880 US\$ in 2008 and 2,000 US\$ in 2009. Consequently, 361, 112 and 39 households, respectively, accepted these cash payments. ${ }^{28}$ Although the amounts of cash increased, a majority of those households who accepted cash compensation were not satisfied because accepting the cash offered no sustainable livelihoods for their families.

In 2010, local and international NGOs found out that unrefined sugar was being exported from Cambodia to the parent company in Thailand, Khon Kaen Sugar Industry (KSL), for final refining. Through the European Union's Everything But Arms (EBA) scheme, the sugar was then sold to Tate and Lyle (T\&L) in the United Kingdom. Given this information, the communities and local NGOs filed a complaint with the National Human Rights Commission of Thailand (NHRC-T). A lawyer said that the NGOs, on behalf of the communities, also wrote letters to T\&L to complain about the adverse impacts of its sugar suppliers in Cambodia, but no solution was provided by T\&L. ${ }^{29}$ 
In May 2012, the remaining 200 families from the communities, with the assistance of the NGOs, filed a complaint against T\&L with the UK courts to seek addressing of their demands. The representative claimed that the court started to investigate and promised to try the case, but there has been no significant result so far. ${ }^{30}$ Meanwhile, the communities, through local NGOs, filed a complaint to the EU in Cambodia and in Brussels to report the EBA's adverse impact. ${ }^{31}$ So far, the EBA has tried to mediate the dispute but this has yielded no fruitful results besides acknowledgement of the adverse impacts. ${ }^{32}$

In response to this international and local pressure, the government and sugar company on the one hand suppressed the communities, and on the other offered increased but unacceptable compensation. In late 2012, the communities claimed that the cash compensation was increased to 3,120 US\$ per household. Twenty-one households opted for the offer and pledged no more complaints and protests. As of late 2013, cash compensation was increased to above 3,120 US\$ per family, but none of the remaining families accepted the offer because, as noted above, the case offered no long-term solution for them. ${ }^{33}$ To repress the communities, the government resisted their allegations by accusing the remaining families who did not accept cash compensation of being involved in opposition party movements, although the communities have claimed to have an apolitical stance: the government claimed 'they are the opposition party's activists who tried to overthrow the government' ${ }^{34}$ Another reason which bolsters this accusation is the fact that, during the 2013 election, the opposition party set its agenda on land issues and promised to return all land expropriated by land speculators and large-scale ELCs. A member of parliament of the opposition party once questioned the concerned ministries, especially the Minister of Agriculture, at the national assembly, but could not influence these ministries to address the demands of the sugarcane movement. This demonstrates the inclinations of these ministries to protect the rent extraction of the senator. Given this political reasoning, the communities could not continue their protests; otherwise they would have faced severe repressive measures: ${ }^{35}$ 'Now, we cannot hold protests anymore, we otherwise step on footprints of the opposition party that would result in severe repression and 
charge.' ${ }^{36}$ This strategy is generally known as one used by the ruling party to tarnish movements that could benefit the opposition parties, especially given the 2013 election result. However, where possible, it co-opted those (families) who appeared to support the ruling party.

Despite the PM's 2012 order to reallocate land to the affected communities, the sugar company has resisted. The provincial governor, furthermore, has claimed that, because the land is still in dispute, the government and sugar company cannot reallocate it. This is due in fact to the senator's influence on the provincial office and provincial sectoral department of land, environment and agriculture not to enforce the order in this area. This suggests that the senator -known as a strongman and king of Koh Kong's business - has 'captured' the neo-patrimonial process (and the central patron), given his indispensable roles in the regime in general and in the ruling party in particular. The notion argued by Soule (2009) that the state or government has authority to regulate the company in favour of movement groups does not apply in this context.

In light of the above evidence, the mobilisation strategies of the communities appear to have effective influence on the government or the sugar company to address their demands. Although some achievements, such as capacity building and empowerment of the communities, advocacy, networking, and media coverage, have been taken into account, the movement has relatively failed to achieve most of its demands. This is because the government has opted for more repressive than concessive measures in response to the communities. For example, the communities received only cheap cash compensation.

Their relative failure to achieve their demands appears to have been determined not by their influencing strategies, but shaped by the strong patron-client network between the sugar company and the neo-patrimonial government. In particular, although the communities and NGOs invested great effort to leverage pressure, they still faced repressive measures (violent crackdowns, politicisation and other forms of intimidation) of the government. In this investment, the patronclient network was constructed when the Thai and Taiwanese investors sought a joint venture with the powerful senator, known to be a close friend of the PM, to gain access to land and to secure 
long-term investment. In spite of the adverse impacts and the persistent resistance of the communities, the investment has operated smoothly. This appears due in part to the sugar company, the client, being protected by the central patron (the PM) for what Scott (1972) calls 'reciprocal benefits'. As explored in the third section of this paper, benefits (rents) from such investments are important in maintaining the power of the patron.

\section{Why do movements of some communities succeed but others fail?}

Answering the question of why some communities succeed in achieving most of their stated aims, claims or demands while others fail to do so is concerned with the factors that influence the government to opt for different responses, be it more concessive or more repressive measures. Drawing on the two cases, five independent explanatory factors are identified to have contributed to explaining the relative success or failure outcomes of the movements (dependent variables): i) size of investments; ii) corporate reputation and social responsibility; iii) use of tactics: escalation from non-violent to violent protests, and from domestic to international mobilisations, and international networking; iv) the responses of the government and the companies; and v) patron-client ties between the government and the companies. By tracing how these factors are connected to the outcomes of the community protests, the responses of the government, as theorised earlier, is the vital aspect explaining the relative success or failure outcomes. Hence, the factors that explain the latter decisively are those that correlate significantly with the responses of the government, either with concessive or repressive measures. As evidence in the two cases suggested, while the first three factors are found to have a certain influence on the different responses of the government, the different level of entrenchment of patron-client networks in this neo-patrimonial regime is the predominant one. It influences the government to opt for these different responses, which subsequently shape the responses of the companies, and they ultimately shaped the relative success and failure in these two cases. 
As the two cases suggested, whether or not the two companies concede to the community movements, it is not a matter of the different sizes of the two agro-industrial investments and land. The concessions (land and cash payment) made by the rubber company were not due to its smaller land and investment capital, and the concessions (cash payment) by the sugarcane company was not due to its larger capital and land size. For instance, the rubber company caused adverse impacts on 850 families, but only around 500 families were affected by the sugarcane company's land expropriation. In a conversation with the general manager, he said that his company managed to get another concession nearby the current one, and in total it has a land size comparable to the sugarcane company. Land and investment size are partial factors explaining the processes of the movements, but they do not link precisely to the success or failure of the respective cases, especially to the conditions that motivate the government to concede to or repress the movements.

Apart from the investment size, the two companies employed different corporate social responsibility (CSR) aiming to address the communities' demands. The rubber company's CSR approach was better compared to the sugarcane company. Although the company's reputation in the international rubber market is a concern, the rubber company would not reallocate the land without the order of the government. In spite of its contribution to the company' concessive solutions for the indigenous communities, CSR did not correlate with or explain why the government opted for concessive responses. CSR was a rubber company's initiative to harmonise their relation with the communities. Meanwhile, in the sugarcane case, the community was not impressed by the sugarcane company's CSR approach. The community alleged that the sugarcane company resorted to CSR in order to cover its malpractice behind the scene; their CSR activities did not accommodate the actual claims of the community. CSR is thus an element that describes the interaction of the company with the communities, but it does not explain concessive and repressive responses of the government which later define the relative success or failure of the two communities.

The tactics and organisations of the movements - including escalation from non-violent to violent protests, and from domestic movements to international networking, formal and informal 
organisational arrangement, resource mobilisation/support, and seeking ties with political elites appear to be necessary for explaining the dynamics of the movements. They are necessary because they were part of the interactions that partially led to the responses of the government and the companies, but they are not decisive for explaining the simultaneous success or failure of the two movements. It is argued so due to the evidence that the strong influencing strategies of the sugarcane case - consisting of networking formal organisation and resourceful supports (in terms of sustaining long-term mobilisation) from NGOs for more than a decade — resulted in the relative failure to attain most of their demands, but the weak influencing strategies of the rubber case stimulated their relative success in achieving most of their demands although they were informal, and received no technical assistance from local and international NGOs. To reiterate, these factors do not explain decisively the simultaneous repressive and concessive measure of the government towards the companies as well as the outcomes of the two movements.

To invest in this regime, foreign investors usually have to form networks or join ventures with Cambodian politico-commercial elites or tycoons. Without such networking, as pointed out by a general manager of an ELC, it is otherwise difficult to secure long-term investment. ${ }^{37}$ A chief executive officer of another ELC confirmed that, in the ELC sector, it is common that powerful tycoons, politicians, military officials or those with strong political connections with the central patron are granted ELCs. ${ }^{38}$ The two joint venture companies in this study chose slightly different paths to accessing agricultural land. The rubber company preferred to take over the majority of the local partner's shares, while the sugar company chose to connect with a powerful politician. This suggests a different level of entrenched patron-client networks between the foreign investors and the elites. The rubber company appears to have possessed a comparatively weak network with the central patron, whereas the sugar company had a very strong political network. In the sugar case, a provincial governor affirmed that the senator acted as a local partner to facilitate access to the land. Although it is controversial, he said, in return for the senator's effort, 'they [foreign investors] give $10 \%$ of the shares, to speak frankly'. ${ }^{39}$ This evidence shows how the networks of the regime exploit 
foreign capital to extract more rent which buttresses the regime's electoral legitimacy, as also pointed out by a number of scholars (Milne 2015). Annually, the senator contributed 300,000 US\$ to Cambodia Red Cross (CRC) which is managed by the PM's wife. He said, 'I have donated this amount every year for a long time' (Sovuthy 2015). CRC is an office where gifts are distributed in favour of the ruling party. The PM once impressed the senator for his contribution to local development, which is a mechanism to mobilise electoral support as suggested by many studies (Pak 2011). The PM said during the inauguration of the senator's sugar factory:

I have learned of and trusted his work in relation to his investment in building the bridge across the seacoast at Koh Kong province [...]. The company has gained my trust. Because of his success, I provide him and his partners from abroad with more chances so that he can work to set up more local developments. ${ }^{40}$

This different degree of relation stimulated different government responses towards the two communities. Corroborating with Scott (1972), the patron of the regime tends to protect clients for reciprocal, although not equal, benefits. This is clearly shown in the case of the sugarcane agroindustry, where the government (patron having the PM as a chair) protected the client (the senator and his partner), who helped the patron mobilise electoral support. To protect the client, the patron opted for more repressive than concessive measures in response to the movements of the communities. Given this, the sugar company aligned with the government response and resisted addressing the adverse impacts raised by the affected communities. On the contrary, given that the rubber company possessed weak political ties with the patron, the government thus opted for more concessive than repressive measures in response to the indigenous communities. Coupled with its fairly strong CSR, code of conduct, and protection of its international reputation, the rubber company complied with the government responses by addressing the demands of the indigenous communities. Having most of their demands addressed by the rubber company and the government, the indigenous community movements achieved relative success. In the political context of 
Cambodia, why some movements succeed while others fail is decisively explained by the different strengths of the patron-client networks that are entrenched in the neo-patrimonial regime, although other factors, including the influencing strategies (violent and non-violent protests, resource mobilisation, transnational networking) of the two communities, remain necessary. Situated within this neo-patrimonial arrangement of political survival, the patterns of relative success or failure of communities in achieving their demands are shaped by the manoeuvring of the regime's concession and repression policies (Young 2016c).

Among several cases of failure, a movement against the agro-sugar industry in Kampong Speu province, which is owned by the same tycoon of the sugarcane case, is an example of patronage ties between an individual with the ruler of the regime. So far, the movement has not achieved their demands, reclaiming the land back. The NGO which was behind the movement got their activities suspended and shut down for a while, as ordered by the Ministry of Interior (MoI). The NGO was alleged by MoI of not complying with their bylaws submitted to the MoI when they first registered. Likewise, protests of affected communities against a strongly politically connected company, namely, Pheapimex, in Kampong Chhnang and Pursat provinces achieved neither acceptable results nor compensation (Work 2015). In the Kampong Chhnang province, the lingering case of Lar Peang community resistance against a company owned by the wife of a powerful (mine and energy) minister has not been solved. This community encountered more repressive measures orchestrated by the provincial and local authorities. The aims were to protect the economic interests of the political figure's rent. In contrast, movements of affected communities against a Korean company in Kratie province received a relatively successful outcome. The government ordered the Korean company, which is known to have established no strong ties with the ruling elites, to return about 1,562 hectares of land to the affected communities (Schoenberger 2017).

\section{Concluding discussion: Success and failure in a neo-patrimonial regime}


This paper has argued that the patron-client networks of neo-patrimonial politics shape the degrees of success or failure of social movements. To unpack this hypothesis, the paper has illustrated one case of relative success and one of failure of community movements in demanding that the government and companies address their grievances. The paper has postulated that theoretical factors raised by previous scholars, such as transnational advocacy networks, tactics, resources and political contexts, are necessary but not decisive for explaining the variation in outcomes, success or failure, of the community movements within neo-patrimonial politics where rulers have clung onto power.

In particular, although the communities in the sugarcane case employed both local and international influencing strategies, including international networking, they still failed. Influenced by the notion of transnational advocacy networks of Keck and Sikkink (1998), these local and international networks leveraged little pressure on either the sugar company or the government. This shows that the international network of the grassroots communities, which was supported by local and international NGOs, did not exert significant pressure on the stakeholders at each stage of the sugar supply chain. This confirms that great resource mobilisation by the communities and NGOs did not affect the outcome, as claimed by Edwards and McCarthy (2004). The resource mobilisation hypothesis cannot explain substantially the success or failure of these community movements. The indigenous communities in particular, without support from NGOs, relatively succeeded in achieving their demands. From a tactical perspective, the non-violent approach of the communities in the sugarcane case relatively failed to achieve their demands; this is different from what Stephan and Chenoweth (2008) theorise - that is, that non-violent tactics tend to achieve the desired outcomes. With less support from NGOs, the indigenous communities, on the contrary, shifted their tactics from non-violent to violent tactics in order to exert influence directly on the rubber company, after the government failed to address their demands in their first attempt. Even though the government did not repress the violent tactics immediately, the ringleaders were detained afterwards. The reason for not cracking down on the violent protests was, on the one hand, 
the fear of mounting violent protests, and on the other the desire to maintain goodwill and the image of the government. In this respect, the tactical notion of Gamson (1990), Steedly and Foley (1979) and Stephan and Chenoweth (2008) is not decisive for explaining relative success or failure in either the rubber or the sugarcane cases.

Political opportunity structure theorists, such as Amenta et al. (1999) Amenta et al. (2002) and Kitschelt (1986), suggest that, among other aspects, if movements can involve political elites who possess decision-making power within the political system in a given opportunity, they will succeed (Sikkink 2005). The two cases strove to involve a number of political elites and institutions of the regime to intervene in their cases, but they still received different outcomes. In particular, the indigenous communities were not so active to engage a number of governmental institutions, but they relatively succeeded. In a different way, the sugarcane movements were active in mobilising assistance of political elites from within both the ruling and opposition parties, but they relatively failed due to an influential owner of the agro-sugar industry. These lessons learnt suggest that the opportunities were given for the movements to bring in the political elites from within the neopatrimonial regime, but the political system was controlled and was not opened by a central patron whose decisions affected not only those politicians within its system but also the opposition party. Within the neo-patrimonial system, those with weaker power cannot oppose those with strong political connections (e.g. the senator) with the regime's patron; especially in the case of sugarcane, the secretary of state of the MoI, and the member of parliament of the opposition party offered no help to the communities. This implies that opportunities emerge within the neo-patrimonial political structure, but the patronage system (the powerful patrons) barricades those individual politicians (less powerful clients) to mobilise inner institutional support to assist the movements. The openness of the institutions in this regime is very limited and selective, as the regime's patrons tend to control the subordinators strictly for the sake of their power. In essence, political opportunity structures within social movement literature do not translate to a hybrid regime like Cambodia. The concept does not explain why the government opted for different responses to different movements. 
Similar to political opportunity structure, political contexts, which suggest that the authoritarian regime tends to be repressive, whereas the democratic one appears to be more concessive to the movements (Amenta et al. 2010; Cress and Snow 2000), remain inconclusive to explain the degrees of success and failure of the movements that involved not only the government but also corporations, as in this study. In the rubber case, the rubber company, based on its code of conduct and CSR, was more independent of the government. However, the company appeared to be well regulated by the government as suggested by Soule (2009) that, the movements tend to target the government in the hope of regulating the companies to address the movements' demands. The CSR approach was employed as a mode of response of the rubber company to comply with regulatory enforcement of the government. This response shapes, but not significantly, the relative success of the indigenous communities. The concept of political context explains some of the failure of the sugarcane case, but it remains too broad to explain the conditions that stimulated the government to repress those communities. The relative success or failure is, rather, explained by the political dynamics of patron-client networks within a neo-patrimonial regime - an explanation which has not been paid attention by scholars such as Amenta et al. (2010) or Cress and Snow (2000). These scholars have, instead, focused on the movement aspect, which involves the influencing strategies (violent and non-violent tactics, resource mobilisation and networking) as independent factors for explaining the different outcomes. However, in attempting to explain the relative success or failure, these scholars appear not to have taken into account the significance of the patron-client networks between the government and companies in a neo-patrimonial arrangement where the rulers have striven to remain in power. The political dynamics of the neopatrimonial regime, in terms of the patron-client networks, have significant influence on the choice between concessive and repressive responses on the part of the government. Its responses subsequently shape not only the different responses of the companies, but also the variation in outcomes - that is, the relative success or failure of the movements. 
The relative failure to achieve the demands in the sugarcane case is, rather, defined by the patron-client networks of the neo-patrimonial regime. In order to protect the business and political interests of its politico-commercial clients, including the senator, the government orchestrated stronger repression than concession as a response to the disgruntled communities. As defined in the third section, the clients not only shared the accumulated wealth with the central patron to influence political outcomes/elections, but also mobilised electoral support from communities elsewhere. Unlike the sugarcane case, the indigenous communities succeeded because of a weak patron-client network between the rubber company and the central patron. Since the local partner of the rubber company did not possess strong political ties with the government, the government opted for more concessive than repressive measures to placate the aggrieved indigenous communities. In addition to how the government responded to each grassroots social movement, the dynamics of regime survival since the 2013 election suggest that the regime has had to manoeuvre itself towards a more concessive policy, addressing the grievances of the community movements which otherwise threaten the regime.

The study concludes by contending that, while these factors (use of tactics, resource mobilisation, political opportunities and context, and transnational networking) are necessary, they are not decisive to explain the variation in outcomes, that is, the success or failure, of social movements in Cambodia. Rather, within this neo-patrimonial regime, the degree of success or failure of community movements is decisively explained by the rulers' choice between repressive and concessive policies, which are selectively enforced in the different contexts of patron-client networks. On the one hand, the patron protects the client's economic interests in turn for political support and loyalty. On the other hand, the patron sacrifices the clients with weak political ties to placate communities in order to cultivate political support. Within the context of such a neopatrimonial regime's survival, these concessive policies, including the recent moratorium on ELCs and reallocation of the revoked ELCs (albeit at the expense of some concessionaires), suggest the ruling party has striven to restore its image and so accommodated the grievances of communities 
which might rebel against the regime. This is reflected in the cases of the Areng Valley and Prey Lang forest protection movements.

Although these concluding arguments are based on just two cases, the arguments could also explain other cases in Cambodia (see examples above) and other political contexts similar to the neo-patrimonial system. In Cambodia, grassroots movements targeting the government and companies are flourishing. To explain why some of these movements fail while others succeed, the patron-client networks between the rulers of the government and companies within the dynamics of political survival of the neo-patrimonial regime should not be taken for granted. To a limited theoretical extent, these concluding arguments could also explain the success or failure of movements that target both the government and companies in other political systems, including hybrid or authoritarian regimes, whose characteristics and patterns of public and private connections are similar to neo-patrimonial politics. Protests of local communities in Indonesia, Malaysia and the Philippines, for example, faced government's responses similar to this study (see Franco 2008; Gellert 2010) as their regimes are similarly ruled by neo-patrimonial leaders (see Brown 2003). Peasant protests to reclaim land in Africa, where the concept of neo-patrimonialism was drawn upon by Bratton and Van de Walle (1994), encountered similar outcomes, a mixture of success and failure, as those countries in Southeast Asia (see Moyo and Paris 2005).

\section{Acknowledgements}

The author would like to thank Chiang Mai University School of Public Policy for the support at the initial stage of writing this paper, and the European Research Council-funded project entitled PHOTODEMOS (Citizens of photography: The camera and the political Imagination) at the University College London, for supporting the finalisation of the article. The author thanks Kate MacDonald and Andrew Walter, the editors as well as the anonymous reviewers of the journal for their valuable comments. 


\section{Funding}

The author received financial support for the research and finalisation of the article for publication from the European Research Council funded project entitled PHOTODEMOS (Citizens of photography: The camera and the political Imagination), grant no. 695283, at the University College London, UK.

\section{Notes}

1 Fieldwork started in August 2013 and finished in January 2014. In addition to four Focus Group Discussions (FGD), the author interviewed 35 participants, including staff of companies, community representatives; key experts (NGOs, researchers, consulting firm, lawyers, and academic and research institution) who were directly involved in the two cases; and government officials (village heads, commune councillors, senior provincial officials, former ministers and members of parliament).

2 Here 'legitimacy' is defined as maintaining electoral support regardless of election irregularities, manipulation, vote-buying and coercion.

3 All names are anonymised according to the consent agreed between the author and study participants. The size of each concession area is not given exactly.

4 Representatives III and IV (Pichea Da, 18 November 2013).

5 Village head III (Pichea Da, 19 November 2013).

6 Representatives VI (Pichea Da, 18 November 2013).

7 Village head III (Pichea Da, 19 November 2013).

8 Representative VI (Pichea Da, 18 November 2013).

9 Representative VI (Pichea Da, 18 November 2013).

10 Representative VI (Pichea Da, 18 November 2013). 
11 Governor II (Senmonorom, 10 January 2014).

12 Governor II (Senmonorom, 10 January 2014).

13 Representative II (Pichea Da, 18 November 2013).

14 Manager II (Pichea Da, 23 December 2013).

15 Representatives III and IV (Pichea Da, 18 November 2013).

16 Manager II (Pichea Da, 23 December 2013).

17 Manager II (Pichea Da, 23 December 2013).

18 Representatives III and IV (Pichea Da, 18 November 2013).

19 Governor II (Senmonorom, 10 January 2014).

20 The list has not been officially disclosed.

21 Manager II (Pichea Da, 23 December 2013).

22 Governor II (Senmonorom, 10 January 2014).

${ }^{23}$ Governor II (Senmonorom, 10 January 2014).

${ }_{24}$ Representatives I (Sre Ambel, 01 November 2013) and II (Sre Ambel, 02 November 2013).

25 Representatives I (Sre Ambel, 01 November 2013) and II (Sre Ambel, 02 November 2013).

26 Representatives I (Sre Ambel, 01 November 2013) and II (Sre Ambel, 02 November 2013).

27 Manager - NGO II (Phnom Penh, 06 December 2013).

28 Representatives I (Sre Ambel, 01 November 2013) and II (Sre Ambel, 02 November 2013).

29 Lawyer (Phnom Penh, 20 December 2013).

30 Director - NGO (Phnom Penh, 06 December 2013. The trial was postponed to the end of 2015 (but no information was received by the end of 2015).

31 The EU's EBA offers Least Developed Countries (LDC) full duty-free and quota-free access to the EU for all their exports, with the exception of arms and armaments. Cambodia is among the 49 beneficiary countries (see http://trade.ec.europa.eu/doclib/docs/2013/april/tradoc_150983.pdf\%3E.).

32 Representatives I (Sre Ambel, 01 November 2013) and II (Sre Ambel, 02 November 2013). 
${ }^{33}$ Representatives I (Sre Ambel, 01 November 2013) and II (Sre Ambel, 02 November 2013).

34 Village head I (Sre Ambel, 03 November 2013).

35 At that time, the opposition party was protesting in the capital city and some provinces.

36 Informal discussion with a highly-trained activist and media reporter in village C (Sre Ambel, 02 November 2013).

37 Manager IV (Phnom Penh, 27 November 2013).

38 Chief executive officer (Sre Ambel, 18 December 2013).

39 Governor I (Koh Kong, 15 December 2013).

${ }^{40}$ Hun Sen's speech during the inauguration of sugar processing factory in Chikor Leu on 25 January, 2010, available at from http://cnv.org.kh/selected-comments-at-the-inauguration-of-thesugar-factory-in-chikhor-leu-commune-sre-ambel-district-of-koh-kong-province/ (last accessed on 7 December, 2016) 


\section{References}

Adler, Daniel, Kristina Chhim, Path Heang, Sochanny Hak, Ketya Sou and Kimvan Heng (2006) Justice for the Poor? An Exploratory Study of Collective Grievances over Land and Local Governance in Cambodia, Phnom Penh: World Bank and Center for Advanced Study.

Amenta, Edwin, Neal Caren, Elizabeth Chiarello and Su Yang (2010) 'The political consequences of social movements', Annual Review of Sociology 36: 287-307.

Amenta, Edwin, Neal Caren, Tina Fetner and Michael P. Young (2002) 'Challengers and states: Toward a political sociology of social movements', Research in Political Sociology 10: 4783.

Amenta, Edwin, Drew Halfmann and Michael P. Young (1999) 'The strategies and contexts of social protest: political mediation and the impact of the Townsend Movement in California', Mobilization: An International Quarterly 4(1): 1-23.

Bratton, Michael and Nicholas Van de Walle (1994) 'Neopatrimonial regimes and political transitions in Africa', World Politics 46(04): 453-89.

Bratton, Michael and Nicholas Van de Walle (1997). Democratic experiments in Africa: Regime transitions in comparative perspective. London: Cambridge University Press.

Brown, David (2003) The state and ethnic politics in Southeast Asia, London: Routledge.

Bosi, Lorenzo, Marco Giugni and Katrin Uba (2016) 'The Consequences of social movements: Taking stock and looking forward', in Lorenzo Bosi, Marco Giugni and Katrin Uba, eds, The consequences of social movements, 3-38, Cambridge: Cambridge University Press.

Cai, Yongshun (2010) Collective resistance in China: Why popular protests succeed or fail, Stanford: Stanford University Press.

Cambodian Human Rights and Development Association (ADHOC) (2014) Land situation in Cambodia 2013, Phnom Penh: ADHOC.

Chenoweth, Erica and Maria J. Stephan (2011). Why civil resistance works: The strategic logic of nonviolent conflict. New York: Columbia University Press. 
Clapham, Christopher S. (1985) Third world politics: An introduction, Madison: University of Wisconsin Press.

Cress, Daniel M. and David A. Snow (2000) 'The outcomes of homeless mobilisation: The influence of organisation, disruption, political mediation, and framing', American Journal of Sociology 105(4): 1063-104.

Edwards, Bob and John D. McCarthy (2004) 'Resources and social movement mobilisation', in D. Snow, S. Soule and H. Kriesi, eds, The Blackwell companion to social movements, 116-52, London: Blackwell Publishing.

Erdmann, Gero and Ulf Engel (2007) 'Neopatrimonialism reconsidered: Critical review and elaboration of an elusive concept', Commonwealth and Comparative Politics 45(1): 95-119.

Fox, Piven F and Richard A. Cloward (1993) Regulating the Poor: The Functions of Public Welfare, New York: Pantheon Books.

Franco, Jennifer C. (2008) 'Making Land Rights Accessible: Social Movements and Political-Legal Innovation in the Rural Philippines', Journal of Development Studies 44(7): 991-1022.

Gamson, William (1990) The strategy of social protest, Belmont, California: Wadsworth Pub.

Gamson, William A. and David S. Meyer (1996) 'Framing political opportunity', in D. McAdam, J. D. McCarthy and M. Zald, eds, Comparative perspectives on social movements, 275-90, Cambridge: Cambridge University Press.

Giugni, Marco (1998) 'Was it worth the effort? The outcomes and consequences of social movements', Annual Review of Sociology 24: 371-93.

Gellert, Paul K. (2010) 'Extractive Regime: Toward a Better Understanding of Indonesia Development', Rural Sociology 75(1): 28-57.

Hughes, Caroline (2003) Political economy of the Cambodian transition, Oxon: Routledge.

International Federation for Human Rights (FIDH) (2011) Cambodia land cleared for rubber, rights bulldozed, Paris: FIDH. 
Kitschelt, Herbert P. (1986) 'Political opportunity structures and political protest: Anti-nuclear movements in four democracies', British Journal of Political Science 16(1): 57-85.

Keck, Margaret E. and Kathryn Sikkink (1998) Activists beyond borders: Advocacy networks in international politics, Ithaca: Cornell University Press.

Marston, John and Chhoun Hoeur (2015) “A "People's" irrigation reservoir on the Tonle Sap floodplain', in S. Milne and S. Mahanty, eds, Conservation and development in Cambodia: Exploring frontiers of change in nature, state and society, 238-57, New York: Routledge.

McAdam, Doug, Sidney Tarrow and Charles Tilly (2001) Dynamics of contention, Cambridge and New York: Cambridge University Press.

Milne, Sarah (2015) 'Cambodia's unofficial regime of extraction: Illicit logging in the shadow of transnational governance and investment', Central Asian Studies 47(2): 200-28.

Milne, Sarah, Kimchoeun Pak and Michael Sullivan (2015) 'Shackled to nature? The post-conflict state and its symbiolic relathsip with natural resources', in S. Milne and S. Mahanty, eds, Conservation and development in Cambodia: Exploring frontiers of change in nature, state and society, 28-50, New York: Routledge.

Moyo, Sam, and Yeros Paris, eds (2005) Reclaiming the land: The resurgence of rural movements in Africa, Asia and Latin America, London: Zed Books.

Meyer, David S. and Debra C. Minkoff (2004) 'Conceptualizing political opportunity', Social Forces 82(4): 1457-92.

Olzak, Susan and Sarah A. Soule (2009) 'Cross-cutting influences of environmental protest and legislation', Social Forces 88(1): 201-25.

Pak, Kimchoeun (2011) A dominant party in a weak state: How the ruling party in Cambodia has managed to stay dominant, PhD dissertation, Australian National University.

Parnell, Terry (2015) 'Story-telling and social change: A case study of the Prey Land Community Network', in S. Milne and S. Mahanty, eds, Conservation and development in Cambodia: Exploring frontiers of change in nature, state and society, 258-79, New York: Routledge. 
Peou, Sorporng (2001) 'Cambodia after the killing fields', in F. John, ed., Government and politics in Southeast Asia, 36-73, Singapore: Institute of Southeast Asian Studies.

Schoenberger, Laura (2017) 'Struggling against excuses: winning back land in Cambodia', Journal of Peasant Studies 44(4): 870-90.

Scott, James C. (1972) 'Patron-client politics and political change in Southeast Asia', American Political Science Review 66(1): 91-113.

Sikkink, Kathryn (2005) 'Patterns of dynamic multilevel governance and the insider-outsider coalition', in D. Della Porta and S. Tarrow, eds, Transnational protest and global activism, 151-73, Oxford: Rowman \& Littlefield.

Soule, Sarah A. (2009) Contention and corporate social responsibility, New York: Cambridge University Press.

Steedly, Homer R and John W. Foley (1979) 'The success of protest groups: Multivariate analyses', Social Science Research 8(1): 1-15.

Stephan, Maria J. and Chenoweth, Erica (2008) 'Why civil resistance works: The strategic logic of nonviolent conflict', International Security 33(1): 7-44.

Sovuthy, Khy (2015, 9 May). 'Cambodian Red Cross raises $\$ 13$ million in fundraiser', Cambodia Daily, 9 May, available at https://www.cambodiadaily.com/archives/cambodian-red-crossraises-13-million-in-fundraiser-83447/ (last accessed on 6 December, 2016).

Tarrow, Sydney (2012) Strangers at the gates: Movements and states in contentious politics, London: Cambridge University Press.

Un, Kheang (2005) 'Patronage politics and hybrid democracy: political change in Cambodia, 19932003', Asian Perspective 29(2): 203-31.

Un, Kheang and Sokbunthoeun So (2011) 'Land rights in Cambodia: How neopatrimonial politics restricts land policy reform', Pacific Affairs 84(2): 289-308. 
Van Dyke, Nella, Sarah A. Soule and Verta A. Taylor (2005) 'The targets of social movements: Beyond a focus on the state', Research in Social Movements, Conflicts and Change 25: 2751.

Weber, Max (1978) Economy and society: An outline of interpretive sociology, Berkeley: University of California Press.

Work, Courtney K. (2015) Intersections of Climate Change Mitigation Policies, Land Grabbing and Conflict in a Fragile State: Insights from Cambodia, The Hague: International Institute of Social Studies and Chiang Mai University.

Young, Sokphea (2016a) 'Movement of indigenous communities targeting an agro-industrial investment in north-eastern Cambodia', Asian Journal of Social Science 44(1-2): 187-213.

Young, Sokphea (2016b) 'Popular resistance in Cambodia: The rationale behind government response', Asian Politics \& Policy 8(4): 593-613.

Young, Sokphea (2016c) The Political economy of contestation over land resources in Cambodia, PhD dissertation, Melbourne: University of Melbourne.

\begin{abstract}
About the Author
Sokphea Young obtained his PhD from the University of Melbourne, Australia, and is currently a Postdoctoral Research Associate at the University College London (UK). He is also affiliated with Chiang Mai University School of Public Policy as an adjunct Research Fellow. His research interests are in the areas of transnational activism, civil society, political culture, visual social media and development, citizenship; globalisation and international development; and political development in Southeast Asia. His research has been published in Journal of International Relations and Development, Journal of Civil Society, Asian Politics \& Policies, Asian Journal of Social Science, and Journal of Current Southeast Asian Affairs, and as book chapters and other working papers.
\end{abstract}

